\title{
Melanoma patients with additional primary cancers: a single- center retrospective analysis
}

\author{
Florentia Dimitriou ${ }^{1}$, Joanna Mangana ${ }^{1}$, Alessandra Curioni-Fontecedro ${ }^{2,4}$, Markus \\ Rechsteiner ${ }^{3}$, Patrick Turko ${ }^{1}$, Ralph P. Braun ${ }^{1,4}$, Reinhard Dummer ${ }^{1,4, *}$ and Phil F. \\ Cheng ${ }^{1, *}$ \\ ${ }^{1}$ Department of Dermatology, University Hospital of Zurich, Zurich, Switzerland \\ ${ }^{2}$ Department of Hematology and Oncology, Division of Oncology, University Hospital of Zurich, Zurich, Switzerland \\ ${ }^{3}$ Department of Pathology and Molecular Pathology, University Hospital of Zurich, Zurich, Switzerland \\ ${ }^{4}$ Faculty of Medicine, University of Zurich, Zurich, Switzerland \\ *These authors contributed equally to this work \\ Correspondence to: Reinhard Dummer, email: reinhard.dummer@usz.ch \\ Phil F. Cheng, email: phil.cheng@usz.ch \\ Keywords: melanoma; additional primary tumors; multiple primary tumors; BRAF V600E mutation; papillary thyroid cancer \\ Received: March 28, $2019 \quad$ Accepted: April 29, $2019 \quad$ Published: May 21, 2019 \\ Copyright: Dimitriou et al. This is an open-access article distributed under the terms of the Creative Commons Attribution License \\ 3.0 (CC BY 3.0), which permits unrestricted use, distribution, and reproduction in any medium, provided the original author and \\ source are credited.
}

\section{ABSTRACT}

Background: Recent progress in the diagnosis and treatment of primary and metastatic cutaneous melanoma (CM) has led to a significant increase in the patients ` expectancy of life. The development of additional primary tumors (APT) other than CM represents an important survival issue.

Results: Of a total of 1764 CM patients, 80 (4.5\%) patients developed APT. For tumors diagnosed after CM, there was a $\mathbf{2 . 7}$ fold excess risk for APT compared to the swiss german population. A significantly increased risk was noted for female breast (SIR, 2.46), male larynx (SIR, 76.92), male multiple myeloma (SIR, 11.2), male oesophagus (SIR, 10.8) and thyroid on males (SIR, 58.8) and females (SIR, 38.1). All thyroid cancer cases had a common papillary histological subtype and a high rate of BRAFV600E mutation. Melanoma was the primary cause of death in the vast majority of patients.

Methods: We used the cancer registry from the Comprehensive Cancer Center Zurich (CCCZ) and retrospectively analyzed patients with CM and APT between 2008 and 2018. We calculated the risk of APT compared to the swiss german population using the standardized incidence ratio (SIR).

Conclusions: Patients with CM have an increased risk for hematologic and solid APT. Long-term follow-up is indicated.

\section{INTRODUCTION}

Cancer is a genetic disease, caused by the accumulation of genetic mutations that eventually transform a normal cell into a tumor cell [1]. It is of great concern for industrial countries due to the increasing incidence rates of the most common forms of cancer, mostly due to the lengthening of human lifespan and population aging [2,3]. Cutaneous melanoma (CM) is, when not diagnosed early, an aggressive skin cancer derived from the melanocytes [4].
Although it represents approximately $5 \%$ of all cutaneous malignancies, it is considered one of the most lethal form of all skin cancers. Recent advances in understanding the molecular mechanisms and the underlying pathogenesis of the disease has led to significant improvements in the diagnosis and treatment and subsequently to an increase of the melanoma survival rates [5]. Due to variable environmental factors resulting in DNA damage, melanoma is associated with a high burden of somatic mutations $[6,7]$. The identification of frequent mutations 
in the MAPK pathway has led to the development of targeted inhibitors, such as BRAF inhibitors (BRAFi) and MEK inhibitors (MEKi), with improved response and overall survival (OS) [8]. On the other hand, melanoma is an immunogenic cancer, conferring sensitivity to immunotherapeutic antibodies, which augment the cellmediated immunity, such as checkpoint inhibitors against cytotoxic T-lymphocyte-associated antigen 4 (CTLA-4) or programmed cell-death protein 1 (PD-1) [9]. Due to this remarkable progress in metastatic melanoma treatment, today, the proportion of patients alive at 24 months in firstline setting is $62.9 \%$ with anti-PD1 plus anti-CTLA4 and $53.5 \%$ with BRAFi and MEKi [10].

Considering the tremendous improvement in the $\mathrm{OS}$, it is also important to focus on survival issues and consequences, such as the development of long-term toxicities and most importantly new, independent tumors of different primaries other than melanoma. SEERdatabase analyses have previously shown that melanoma patients are prone to the development of other primary tumors of different histological type [11] and vice versa; other malignancies have been related to a secondary melanoma development [12-17]. Since the diagnosis and treatment complexity of the patients with additional primary tumors (APT) increases, we retrospectively analyzed melanoma patients with primary tumors of histological type other than melanoma in our melanomareference center. We aimed to describe the distribution of these tumors analog to melanoma diagnosis, underline the complexity of these patients and emphasize the importance of long-term follow-up in patients diagnosed with cancer.

\section{RESULTS}

\section{Study population}

There was a total of one thousand seven hundred and sixty four $(n=1764)$ patients diagnosed with melanoma between 2008 and 2018 with a cut-off of June 2018. Of the 1764 melanoma patients, eighty (4.5\%) patients were diagnosed with an APT, from which thirteen $(16.25 \%)$ patients developed multiple ( $>$ three) separate cancer types of different primary (MPT) (Figure $1)$. The median patient age at melanoma diagnosis was 70 years (33-90 years) and the majority of the patients were males $(65 \%)$. Thirty $(37.5 \%)$ patients had a family history of cancer, with same cancer in first- or seconddegree relatives in $8.8 \%$. $60 \%$ of the patients diagnosed with an APT had metastatic melanoma of which $26.7 \%$ were metastatic to the brain. Since mutational analysis does not belong to the standard tests for patients with non-metastatic melanoma in our institution and $32.4 \%$ of the patients were stage III-IV, mutational status was known in $57 \%$ of the patients. $26.6 \%$ of these patients were BRAF V600 mutated and $16.5 \%$ NRAS. As of June $201869.6 \%$ of the patients with APT were alive. Of the $30.4 \%$ deceased, metastatic melanoma was the primary cause of death in the vast majority of patients $(79.2 \%)$, followed by breast cancer $(8.3 \%)$. Other causes of death were multiple myeloma $(4.2 \%)$, pancreas cancer $(4.2 \%)$ and lung cancer (4.2\%). Patients' characteristics, demographics and features of melanoma are listed in Table 1.

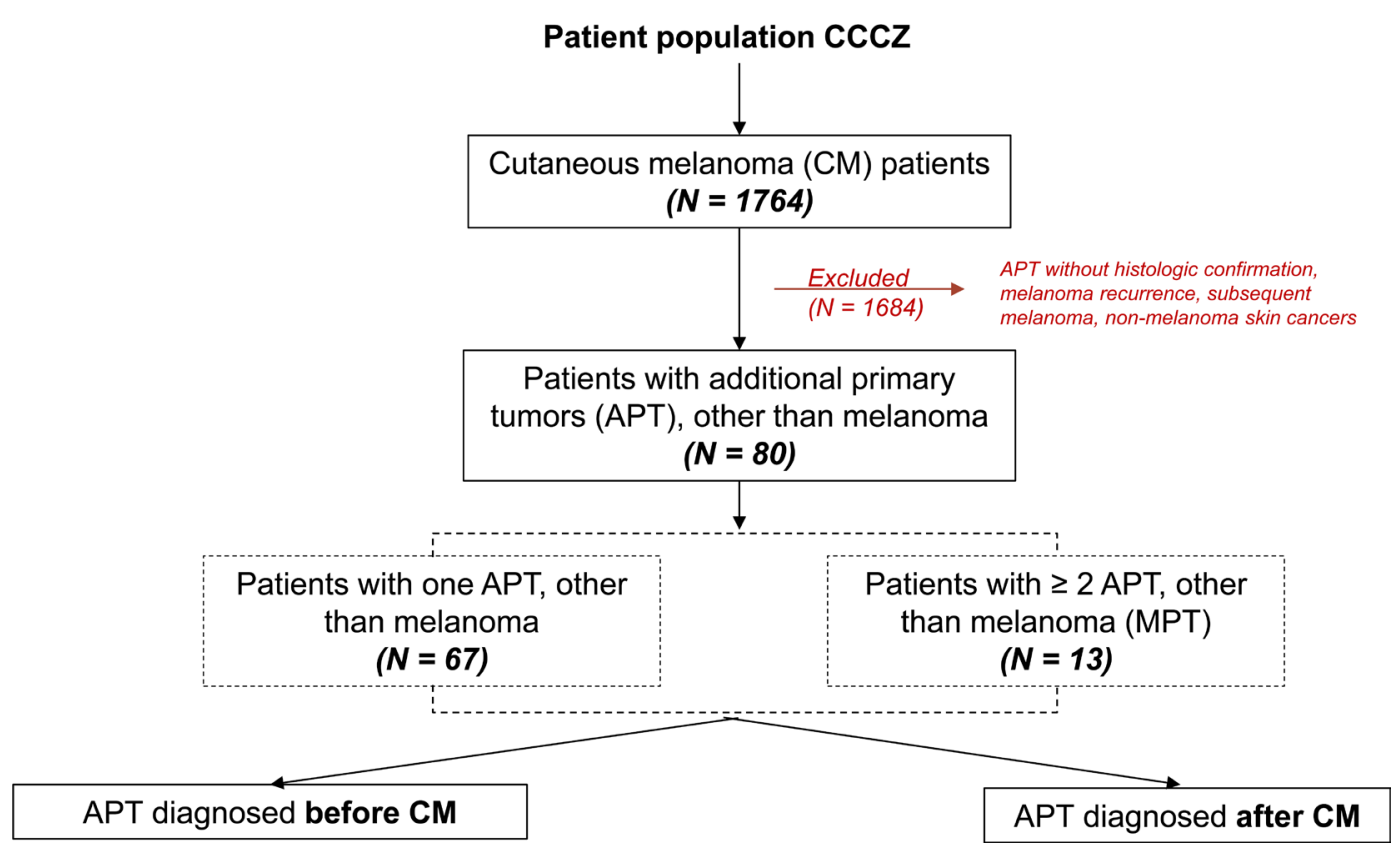

Figure 1: Patient population, CCCZ: Comprehensive Cancer Center Zurich. 
Table 1: Basic demographic characteristics of study population

\begin{tabular}{|c|c|c|}
\hline & & Overall \\
\hline $\mathbf{N}$ & & 80 \\
\hline Age at first diagnosis (median (range)) & & $70(33-80)$ \\
\hline \multirow[t]{4}{*}{ Age group (\%) } & 18,34 & $1(1.2)$ \\
\hline & 35,49 & $7(8.8)$ \\
\hline & 50,69 & $38(47.5)$ \\
\hline & 70,90 & $34(42.5)$ \\
\hline \multirow[t]{6}{*}{ Family history (\%) } & First degree relative same cancer type & $4(5.0)$ \\
\hline & First degree relative different cancer type & $21(26.2)$ \\
\hline & Second degree relative same cancer type & $3(3.8)$ \\
\hline & Second degree relative different cancer type & $2(2.5)$ \\
\hline & No family history of cancer & $36(45.0)$ \\
\hline & Unknown & $14(17.5)$ \\
\hline \multirow[t]{6}{*}{ Smoking (\%) } & No & $57(71.2)$ \\
\hline & 1-9py & $4(5.0)$ \\
\hline & 10-19py & $4(5.0)$ \\
\hline & 20-29py & $5(6.2)$ \\
\hline & 30py+ & $7(8.8)$ \\
\hline & Unknown & $3(3.8)$ \\
\hline \multirow[t]{2}{*}{ Race $(\%)$} & Asian & $1(1.2)$ \\
\hline & White & $79(98.8)$ \\
\hline \multirow[t]{2}{*}{$\operatorname{Sex}(\%)$} & Female & $28(35.0)$ \\
\hline & Male & $52(65.0)$ \\
\hline \multirow[t]{7}{*}{ Localisation of CM (\%) } & Head and neck & $17(21.2)$ \\
\hline & Trunk & $27(33.8)$ \\
\hline & Upper extremities & $9(11.2)$ \\
\hline & Lower extremities & $13(16.2)$ \\
\hline & Acral & $6(7.5)$ \\
\hline & Mucosal and uveal & $3(3.8)$ \\
\hline & unknown & $5(6.2)$ \\
\hline \multirow[t]{8}{*}{ Type of CM(\%) } & SSM & $17(21.2)$ \\
\hline & NM & $25(31.2)$ \\
\hline & LMM & $6(7.5)$ \\
\hline & ALM & $5(6.2)$ \\
\hline & Unknown primary & $6(7.5)$ \\
\hline & Mucosal or Uveal & $1(1.2)$ \\
\hline & Unclassified & $15(18.8)$ \\
\hline & Unknown & $5(6.2)$ \\
\hline \multirow[t]{5}{*}{ Breslow (\%) } & $0-1 \mathrm{~mm}$ & $10(12.7)$ \\
\hline & $1.01-2 \mathrm{~mm}$ & $29(36.7)$ \\
\hline & $2.01-4 \mathrm{~mm}$ & $6(7.6)$ \\
\hline & $>4 \mathrm{~mm}$ & $23(29.1)$ \\
\hline & Unknown & $11(13.9)$ \\
\hline Ulceration (\%) & No & $35(44.3)$ \\
\hline
\end{tabular}




$\begin{array}{lcc} & \text { Yes } & 22(27.8) \\ \text { Mutation Status (\%) } & \text { Unknown } & 22(27.8) \\ & \text { BRAF } & 21(26.6) \\ & \text { NRAS } & 13(16.5) \\ & \text { BRAF wild-type } & 3(3.8) \\ & \text { BRAF and NRAS wild-type } & 5(6.3) \\ & \text { cKIT } & 2(2.5) \\ \text { AJCC Stage at first diagnosis (\%) } & \text { MTOR } & 1(1.3) \\ & \text { Unknown } & 34(43.0) \\ \text { Metastatic Melanoma (\%) } & \text { Stage I or II } & 54(67.5) \\ \text { CNS Metastasis (\%) } & \text { Stage III } & 21(26.2) \\ & \text { Stage IV } & 5(6.2) \\ \text { Status (\%) } & \text { No } & 32(40.0) \\ \text { Death due to (\%) } & \text { Yes } & 48(60.0) \\ & \text { No } & 33(73.3) \\ & \text { Yes } & 12(26.7) \\ \end{array}$

Abbreviations: CM: cutaneous melanoma.

\section{Additional primary tumors (APT)}

In all, we found 93 second primary cancers, accounting also for multiple cancers, diagnosed before and after the first melanoma diagnosis between January 2008 and June 2018. The most frequently observed APT was prostate cancer in males $(24.7 \%)$ followed by breast cancer in females $(15.1 \%)$. Other frequently observed cancers on the overall distribution were bladder cancer (7.5\%), lung cancer $(6.5 \%)$, thyroid cancer $(6.5 \%)$, nonhodgkin lymphoma (5.4\%) and leukemia (5.4\%) (Table 2 ). No predominant leukemia type was found. There was diversity in the stage of first diagnosis of the APT with $31.2 \%$ in stage I, IA and IB and $16.2 \%$ in stage IV and IVA. Consequently, $44.1 \%$ of these APT received curative surgical resection only, $27.9 \%$ received curative resection combined either with radiotherapy $(11.8 \%)$ or with systemic therapy (11.8\%) or both $(4.3 \%)$. Altogether, $30.2 \%$ of the patients in our cohort required a systemic therapy; $10.8 \%$ alone, $11.8 \%$ combined with operation, $1.1 \%$ with radiotherapy, $4.3 \%$ with both operation and radiotherapy and $2.12 \%$ with radiotherapy and bone marrow- or stem cell- transplantation. $6.5 \%$ of the APT were under follow up only. For information on the course of treatment see Table 2 .

\section{Comparison of APT diagnosed before and after melanoma}

We compared the APT diagnosed before (50.5\%) and after $(49.5 \%)$ the first melanoma diagnosis and analyzed for differences in site of occurrence according to sex (Figure 2). Breast cancer in females and prostate cancer in males remain the most frequently observed APT before and after the melanoma diagnosis, with a frequency of $12.8 \%$ and $17.4 \%$ respectively for breast cancer and $36.2 \%$ and $13 \%$ for prostate cancer (Table 2 ). Bladder cancer in males occurs with a frequency of $8.5 \%$ before $\mathrm{CM}$ and $4.3 \%$ after CM. In females, the second most frequent APT is leukemia (8.5\%) before $\mathrm{CM}$ with no cases after $\mathrm{CM}$ and thyroid cancer (8.6\%) after $\mathrm{CM}$ with no cases before $\mathrm{CM}$. In our patient cohort, all thyroid cancer cases were observed after the first melanoma diagnosis in both sexes. On the contrary, the vast majority of hematologic malignancies (leukemia in females and non-hodgkin lymphoma in males) seem to occur before the melanoma diagnosis. Median time to APT diagnosis after CM was 15.91 months (range 0-241.16) and median time to CM after APT diagnosis was 55.37 months (0.30-443.17) (Figure 3). On APT diagnosed before CM, $23.4 \%$ were stage I and $12.7 \%$ 
Table 2: Additional primary tumors` (APT) characteristics

\begin{tabular}{|c|c|c|c|c|c|c|}
\hline & & \multirow{2}{*}{$\begin{array}{c}\text { Both sexes } \\
\text { Overall }\end{array}$} & \multicolumn{2}{|c|}{ Female } & \multicolumn{2}{|c|}{ Male } \\
\hline & & & $\begin{array}{c}\text { After } \\
\text { primary } \\
\text { melanoma }\end{array}$ & $\begin{array}{c}\text { Before } \\
\text { primary } \\
\text { melanoma }\end{array}$ & $\begin{array}{l}\text { After primary } \\
\text { melanoma }\end{array}$ & $\begin{array}{c}\text { Before } \\
\text { primary } \\
\text { melanoma }\end{array}$ \\
\hline$N$ & & 93 & 18 & 14 & 28 & 33 \\
\hline \multirow[t]{22}{*}{ APT type (\%) } & Bladder & $7(7.5)$ & $0(0.0)$ & $1(7.1)$ & $2(7.1)$ & $4(12.1)$ \\
\hline & $\begin{array}{c}\text { Brain \& Central } \\
\text { Nerves }\end{array}$ & $1(1.1)$ & $0(0.0)$ & $0(0.0)$ & $1(3.6)$ & $0(0.0)$ \\
\hline & Breast & $14(15.1)$ & $8(44.4)$ & $5(35.7)$ & $0(0.0)$ & $1(3.0)$ \\
\hline & Cervix Uteri & $1(1.1)$ & $0(0.0)$ & $1(7.1)$ & $0(0.0)$ & $0(0.0)$ \\
\hline & Colon, Rectum & $3(3.2)$ & $1(5.6)$ & $1(7.1)$ & $1(3.6)$ & $0(0.0)$ \\
\hline & Eye & $1(1.1)$ & $1(5.6)$ & $0(0.0)$ & $0(0.0)$ & $0(0.0)$ \\
\hline & Kidney & $3(3.2)$ & $1(5.6)$ & $0(0.0)$ & $1(3.6)$ & $1(3.0)$ \\
\hline & Larynx & $1(1.1)$ & $0(0.0)$ & $0(0.0)$ & $1(3.6)$ & $0(0.0)$ \\
\hline & Leukaemia & $5(5.4)$ & $0(0.0)$ & $4(28.6)$ & $1(3.6)$ & $0(0.0)$ \\
\hline & $\begin{array}{c}\text { Lung, Bronchus, } \\
\text { Trachea }\end{array}$ & $6(6.5)$ & $2(11.1)$ & $1(7.1)$ & $2(7.1)$ & $1(3.0)$ \\
\hline & Merkel & $1(1.1)$ & $0(0.0)$ & $0(0.0)$ & $1(3.6)$ & $0(0.0)$ \\
\hline & Multiple Myeloma & $3(3.2)$ & $0(0.0)$ & $0(0.0)$ & $2(7.1)$ & $1(3.0)$ \\
\hline & Nerve sheath & $1(1.1)$ & $0(0.0)$ & $0(0.0)$ & $0(0.0)$ & $1(3.0)$ \\
\hline & $\begin{array}{l}\text { Non Hodgkin } \\
\text { Lymphoma }\end{array}$ & $5(5.4)$ & $1(5.6)$ & $0(0.0)$ & $1(3.6)$ & $3(9.1)$ \\
\hline & Oesophagus & $2(2.2)$ & $0(0.0)$ & $0(0.0)$ & $2(7.1)$ & $0(0.0)$ \\
\hline & $\begin{array}{c}\text { Oral Cavity \& } \\
\text { Pharynx }\end{array}$ & $3(3.2)$ & $0(0.0)$ & $0(0.0)$ & $1(3.6)$ & $2(6.1)$ \\
\hline & Pancreas & $4(4.3)$ & $0(0.0)$ & $1(7.1)$ & $2(7.1)$ & $1(3.0)$ \\
\hline & Pleura & $1(1.1)$ & $0(0.0)$ & $0(0.0)$ & $1(3.6)$ & $0(0.0)$ \\
\hline & Prostate & $23(24.7)$ & $0(0.0)$ & $0(0.0)$ & $6(21.4)$ & $17(51.5)$ \\
\hline & Stomach & $1(1.1)$ & $0(0.0)$ & $0(0.0)$ & $1(3.6)$ & $0(0.0)$ \\
\hline & Testis & $1(1.1)$ & $0(0.0)$ & $0(0.0)$ & $0(0.0)$ & $1(3.0)$ \\
\hline & Thyroid & $6(6.5)$ & $4(22.2)$ & $0(0.0)$ & $2(7.1)$ & $0(0.0)$ \\
\hline \multirow[t]{13}{*}{$\begin{array}{l}\text { Stage AJCC/ } \\
\text { Rai (\%) }\end{array}$} & I & $20(21.5)$ & $5(27.8)$ & $2(14.3)$ & $7(25.0)$ & $6(18.2)$ \\
\hline & IA & $5(5.4)$ & $2(11.1)$ & $2(14.3)$ & $0(0.0)$ & $1(3.0)$ \\
\hline & IB & $4(4.3)$ & $2(11.1)$ & $0(0.0)$ & $2(7.1)$ & $0(0.0)$ \\
\hline & II & $2(2.2)$ & $0(0.0)$ & $0(0.0)$ & $2(7.1)$ & $0(0.0)$ \\
\hline & IIA & $8(8.6)$ & $2(11.1)$ & $1(7.1)$ & $1(3.6)$ & $4(12.1)$ \\
\hline & IIB & $8(8.6)$ & $1(5.6)$ & $0(0.0)$ & $1(3.6)$ & $6(18.2)$ \\
\hline & III & $6(6.5)$ & $0(0.0)$ & $1(7.1)$ & $2(7.1)$ & $3(9.1)$ \\
\hline & IIIA & $3(3.2)$ & $0(0.0)$ & $1(7.1)$ & $1(3.6)$ & $1(3.0)$ \\
\hline & IIIB & $2(2.2)$ & $1(5.6)$ & $1(7.1)$ & $0(0.0)$ & $0(0.0)$ \\
\hline & in situ & $2(2.2)$ & $0(0.0)$ & $1(7.1)$ & $0(0.0)$ & $1(3.0)$ \\
\hline & IV & $13(14.0)$ & $3(16.7)$ & $1(7.1)$ & $5(17.9)$ & $4(12.1)$ \\
\hline & IVA & $2(2.2)$ & $0(0.0)$ & $0(0.0)$ & $1(3.6)$ & $1(3.0)$ \\
\hline & Unknown & $18(19.4)$ & $2(11.1)$ & $4(28.6)$ & $6(21.4)$ & $6(18.2)$ \\
\hline
\end{tabular}




\begin{tabular}{|c|c|c|c|c|c|c|}
\hline $\begin{array}{l}\text { Treatment } \\
\text { type }(\%)\end{array}$ & None & $6(6.5)$ & $1(5.6)$ & $0(0.0)$ & $4(14.3)$ & $1(3.0)$ \\
\hline & Operation & $41(44.1)$ & $7(38.9)$ & $3(21.4)$ & $12(42.9)$ & $19(57.6)$ \\
\hline & $\begin{array}{l}\text { Operation and } \\
\text { Radiotherapy }\end{array}$ & $11(11.8)$ & $2(11.1)$ & $3(21.4)$ & $3(10.7)$ & $3(9.1)$ \\
\hline & $\begin{array}{l}\text { Operation and } \\
\text { Radiotherapy and } \\
\text { Systemic therapy }\end{array}$ & $4(4.3)$ & $3(16.7)$ & $0(0.0)$ & $1(3.6)$ & $0(0.0)$ \\
\hline & $\begin{array}{c}\text { Operation and } \\
\text { Systemic therapy }\end{array}$ & $11(11.8)$ & $3(16.7)$ & $4(28.6)$ & $3(10.7)$ & $1(3.0)$ \\
\hline & Radiotherapy & $7(7.5)$ & $2(11.1)$ & $0(0.0)$ & $3(10.7)$ & $2(6.1)$ \\
\hline & $\begin{array}{l}\text { Radiotherapy and } \\
\text { Systemic therapy }\end{array}$ & $1(1.1)$ & $0(0.0)$ & $0(0.0)$ & $0(0.0)$ & $1(3.0)$ \\
\hline & $\begin{array}{l}\text { Radiotherapy and } \\
\text { Systemic therapy } \\
\text { and Bone marrow } \\
\text { transplantation }\end{array}$ & $1(1.1)$ & $0(0.0)$ & $1(7.1)$ & $0(0.0)$ & $0(0.0)$ \\
\hline & Systemic therapy & $10(10.8)$ & $0(0.0)$ & $2(14.3)$ & $2(7.1)$ & $6(18.2)$ \\
\hline & $\begin{array}{l}\text { Systemic therapy } \\
\text { and Stem cell } \\
\text { transplantation }\end{array}$ & $1(1.1)$ & $0(0.0)$ & $1(7.1)$ & $0(0.0)$ & $0(0.0)$ \\
\hline \multirow[t]{5}{*}{ Course (\%) } & $\mathrm{CR}$ & $40(43.0)$ & $5(27.8)$ & $6(42.9)$ & $10(35.7)$ & $19(57.6)$ \\
\hline & $\mathrm{PD}$ & $12(12.9)$ & $3(16.7)$ & $2(14.3)$ & $6(21.4)$ & $1(3.0)$ \\
\hline & PR & $1(1.1)$ & $1(5.6)$ & $0(0.0)$ & $0(0.0)$ & $0(0.0)$ \\
\hline & $\mathrm{SD}$ & $39(41.9)$ & $9(50.0)$ & $6(42.9)$ & $12(42.9)$ & $12(36.4)$ \\
\hline & Unknown & $1(1.1)$ & $0(0.0)$ & $0(0.0)$ & $0(0.0)$ & $1(3.0)$ \\
\hline
\end{tabular}

Abbreviations: CR: complete response, PR: partial response, PD: progressive disease, SD: stable disease.

stage IV, whereas on APT diagnosed after 39.1\% were stage I and $19.6 \%$ stage IV (Figure 3). DCR was achieved in $91.5 \%$ on APT before CM and $80.5 \%$ after CM.

For APT diagnosed after CM, we additionally analyzed the patterns of diagnosis, concluding that 28 out of 50 APT were diagnosed at melanoma follow-up, including PET/CT and CT imaging, as well as clinical examination.

\section{Standardized incidence ratio (SIR) analysis}

Although we had a small patient cohort, we calculated the expected number of APT after first melanoma diagnosis assuming that cancer risk in the cohort was similar to that observed in the German Swiss population (Figure 4). We found a few cancers with elevated incidence; breast cancers in females [SIR 2.46 (1.06-4.86)], larynx in males [SIR 76.92 (1.01-427.9)], multiple myeloma in males [SIR 11.2 (1.36-40.6)], oesophagus in males [SIR $10.8(1.31-39.1)]$ and thyroid cancers in both females [SIR 38.1 (10.38-97.54)] and males [SIR 48.8 (5.91-176.2). Overall, we found the SIR for our melanoma cohort to be 2.71 (1.96-3.63).
Interestingly, prostate cancer in males showed a lower incidence after CM diagnosis [SIR $0.69(0.25-1.51)]$.

\section{Cutaneous melanoma and papillary thyroid cancer}

Based on our findings that all thyroid cancer cases $(6.5 \%)$ occurred after the first melanoma diagnosis and due their common papillary pathological type (PTC), although our small patient cohort, we aimed to assess the rate of BRAF V600E mutation in this patient cohort. We therefore performed a real-time quantitative PCR procedure (Idylla) of all available tumor tissues. Six patients with both CM and PTC were tested, of which 4 were found to be positive for BRAF V600E mutation in melanoma, 6 for BRAF V600E in PTC and 4 in both.

\section{METHODS}

\section{Patient selection and data collection}

The cancer registry of the Comprehensive Cancer Center Zurich (CCCZ) is a melanoma reference database 

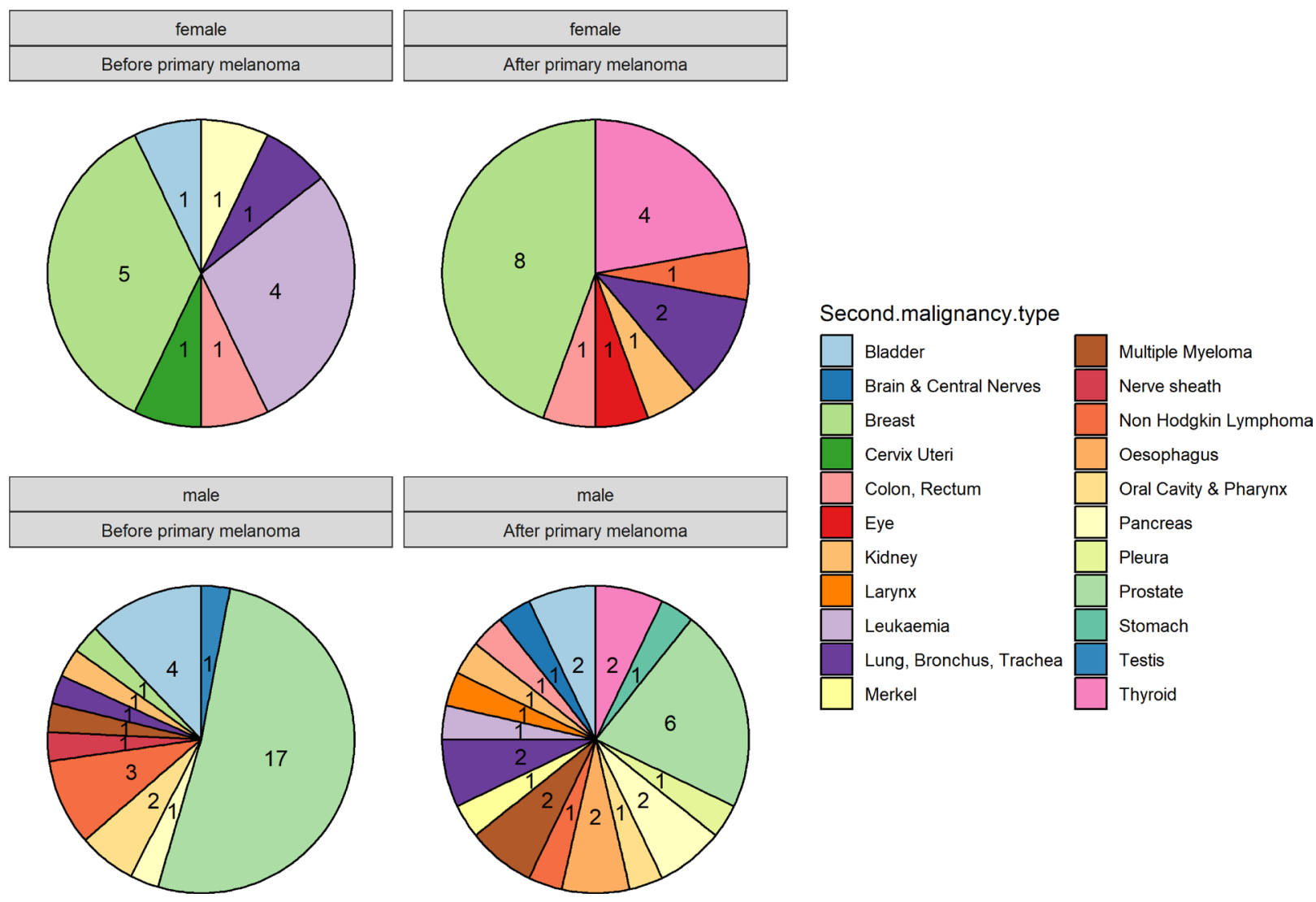

Figure 2: Comparison of additional primary tumors (APT) diagnosed before and after melanoma according to sex.

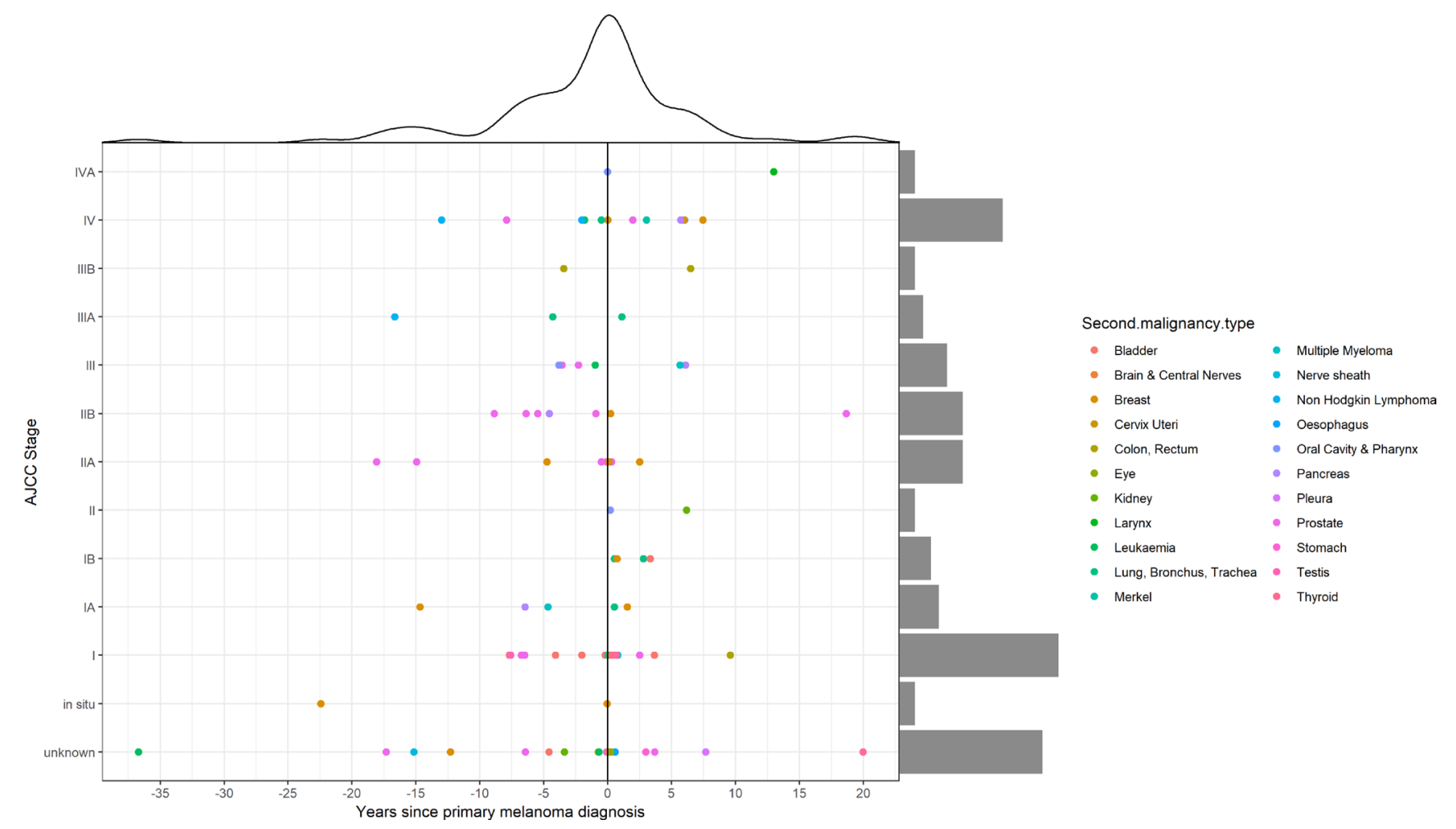

Figure 3: Time and staging distribution of additional primary tumors (APT) according to cutaneous melanoma (CM) diagnosis. 
with centralized data and quality management, for skin cancer. CCCZ was queried for cutaneous melanoma (CM) patients with additional primary tumors (APT) between the years of 2008 and 2018, with a closing date of June 2018 and a minimum follow up time of 6 months. Patients with non-melanoma skin cancers (NMSC) besides Merkel Cell Carcinoma (MCC), melanoma recurrence, subsequent second or third melanomas and benign tumors were excluded. Since APT in patients with metastatic disease are difficult to distinguish from melanoma metastases, we only included APT with a histologic confirmation. The tumors were classified according to the American Joint Committee on Cancer (AJCC) 7th edition. Geographic, histopathologic and treatment data after diagnosis of metastatic disease were retrospectively collected for all patients. Response evaluation to the systemic treatment was according to the radiologic RECIST 1.1 criteria. Patients 'records were also searched for risk factors, including family history, smoke, age, gender and race. In order for the reported variables not to contribute in more than one category, for patients with a first and second degree relative with cancer, only the first degree relative was included. In order to describe the distribution of APT with respect to melanoma diagnosis, we labelled the patients into two groups; APT before and after CM. Multiple primary tumors (MPT) were defined as two or more separate neoplasms of different primary, other than melanoma. Follow-up time was calculated from the day of resection of the CM to the date of last follow-up, including last visit or date of death, or June 2018, whichever occurred first.

For APT occurring after CM, the standardized incidence ratios (SIRs) were calculated by dividing the observed numbers of cancer by the expected ones. The observed numbers of cancers and person-years at risk were calculated by gender, 5-year age group and the time since the diagnosis of CM. The expected numbers of cancer were obtained by multiplying the stratumspecific numbers of person-years by the corresponding cancer incidence rates in German Swiss population in Switzerland extracted from the Nationales Institut für Krebsepidemiologie und -registrierung (NICER) database. Exact 95\% confidence intervals (CIs) were defined when the numbers of observed cases followed a Poisson distribution. All analyses were conducted using statistical language $\mathrm{R}$ version 3.5.

Written informed consent for retrospective analysis of melanoma patients in our registry was previously approved by local ethics committee (KEK-ZH 20140193).

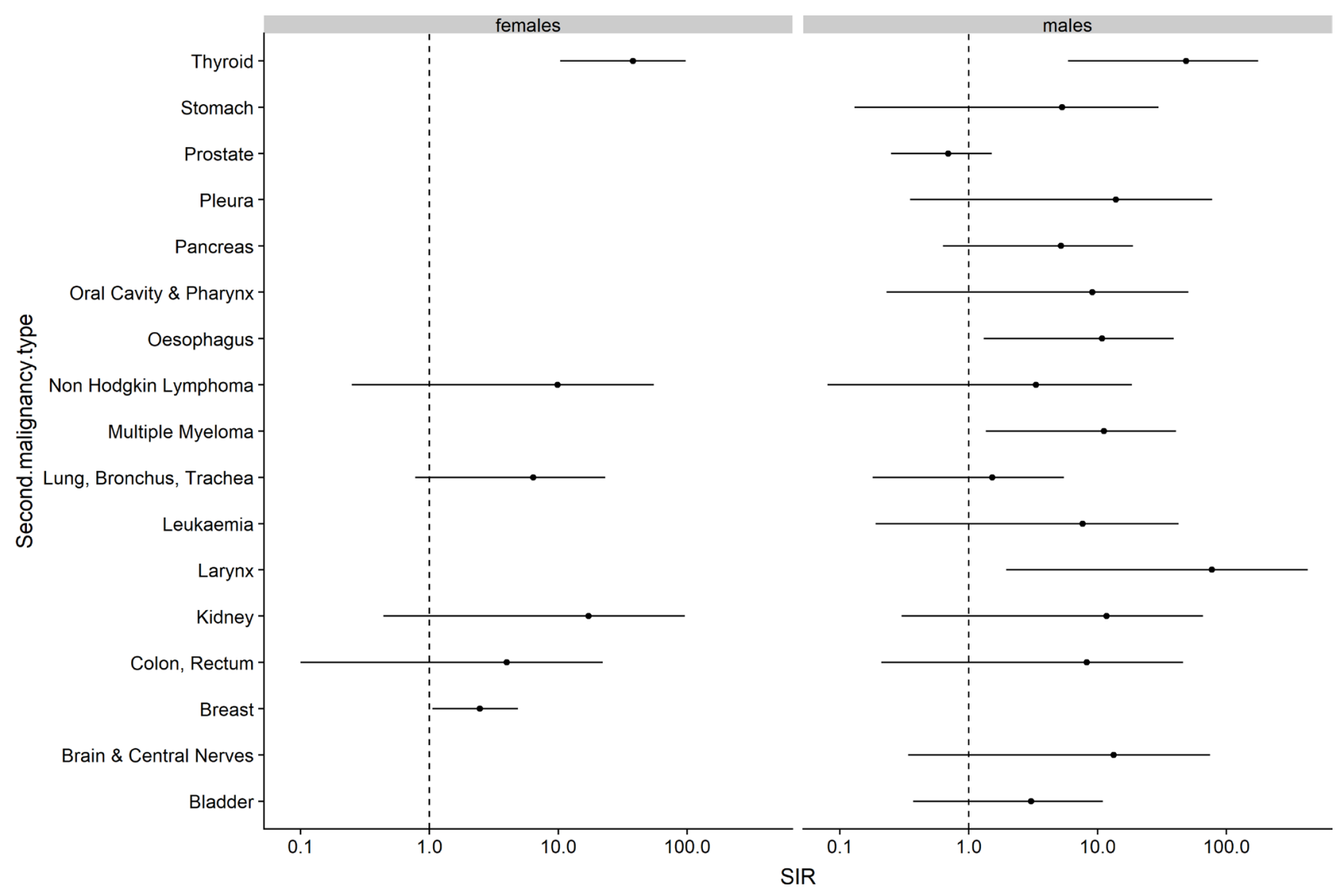

Figure 4: Risk of additional primary tumors (APT) diagnosed after cutaneous melanoma (CM) in the study population compared to the expected cancer incidence rates in the German Swiss population. Abbreviations: SIR: Standardized Incidence Ratios with 95\% Confidence Interval. 


\section{DISCUSSION AND CONCLUSIONS}

On our retrospective analysis, there is an overall incidence of $4.5 \%$ of an APT before and after CM diagnosis, among of which $16.25 \%$ attributed to MPT. Based on our analysis, we show that patients who were previously diagnosed with cutaneous melanoma (CM) have approximately a 2.7 fold increased risk of an APT compared to the general Swiss German population. These results are consistent with previous international findings reporting a significantly elevated risk for specific subsequent primary cancers other than melanoma in melanoma survivors [11], although the relatively greater overall risk of $28 \%$ described in the cited study. Albeit, a direct comparison to these data could be misleading, taking into consideration the differences in the population size, follow-up duration as well as inclusion criteria. Since patients with CM have an increased risk of second primary $\mathrm{CM}$, subsequent melanomas were excluded from our analysis [11, 18-20]. In our patient cohort, female breast cancer, male larynx cancer, male multiple myeloma, male oesophagus cancer and thyroid cancer in both sexes had statistically increased incidence after the first melanoma diagnosis, compared to the normal population. The reasons for this increased risk seem to be multifactorial and could be contributed to increased medical surveillance and follow-up after CM diagnosis, as well as other independent, non-modifiable risk factors, such as the presence of an inherited genetic predisposition and advanced age [21, 22], and behavioral, modifiable risk factors, such as UV-exposure [23] and immunosuppression [24-26], especially for hematologic tumors. A mutual association between $\mathrm{CM}$ and female breast cancer has been reported in both genetic and population-based retrospective studies [27], suggesting a higher prevalence of both cancers for mutations of high-risk genes, such as BRCA2 and CM [28] and $C D K N 2 A$ and breast cancer $[29,30]$. Unorthodoxly, the incidence of prostate cancer in our population seems to decrease after $\mathrm{CM}$ diagnosis, although this result should be cautiously interpreted, due to the relatively low number of this event in our patient cohort. The latter may be of particular interest, since several studies have connected CM and prostate cancer with common risk factors responsible for the pathogenesis of both cancer types, such as the UV exposure, with subsequently increased risk of prostate cancer diagnosis after melanoma diagnosis [12, 16, 31-34]. On the other hand, the role of androgens and oestrogens in the melanoma development have been controversially discussed [35-38]; altogether, the assumption of an additional biological or hormonal relationship between $\mathrm{CM}$, prostate cancer and breast cancer remains unclear.

Interestingly, the probability of a new thyroid cancer diagnosis seems to increase after $\mathrm{CM}$ diagnosis in both sexes, which is in accordance of previous reported results [11]. Besides, the controversial relationship between $\mathrm{CM}$ and thyroid cancer has been confirmed from previous retrospective reviews, suggesting that patients with papillary thyroid cancer (PTC) are at significantly increased risk of CM and vice versa [39]. The precise etiology for this correlation is unclear; however, the thyroid cancer cases observed in our patient cohort had a common papillary histological subtype and a high rate of BRAFV600E mutational background, which was observed in both CM and PTC, thus unravelling a possible common genetic component of these cancers. This is of great importance, considering that several types of cancer are a result of mutations in critical genes [40]. Still, although every individual tumor is genetically distinct, the pathways affected in different tumors may overlap [6]. Approximately $50 \%$ of the CM cases harbor an activating mutation in the $B R A F$ oncogene [41], whereas BRAF V600E mutations have been also described in approximately $44 \%$ of patients with papillary thyroid cancer (PTC) [42]. These results may indicate a common genetic pathway in the pathogenesis of these cancers.

Our dataset showed that in patients with APT or MPT, metastatic melanoma still remains the most common cause of death. Yet, a large proportion of the APT are usually diagnosed on early stages with high DCR rates. There was also a significant difference among the median time of the diagnosis for APT before and after CM ((55.37 months (0.30-443.17) versus 15.91 months (0-241.16)), which can be attributed to the patterns of care after $\mathrm{CM}$ diagnosis with regular screening during follow-up. Indeed, 28 out of 50 APT diagnosed after CM were detected at melanoma follow-up, including PET/CT and CT imaging or clinical examination. The Swiss guidelines recommend an increased vigilance of follow-up in the first 10 years, with surveillance every 3 to 6 months the first 5 years and every 12 months for the next 5 years for the stage I-II melanoma [43]. Patients with a previous diagnosis of $\mathrm{CM}$ are more likely to have more regular and attentive health controls, which may increase the possibility of detecting APT and thus in an early stage. Still, there was a slight difference between stage IV APT diagnosed before (12.7\%) and after (19.6\%) CM, although a possible explanation for this finding is unclear.

The main strength of our study is that the $\mathrm{CCCZ}$ registry provides a high accuracy in tumors registering with long and minimum loss of follow-up. Such patients are usually excluded from clinical trial protocols, thus only few prospective data are available. Our study emphasizes the complexity of patients with unrelated APT and the importance of increased follow-up for the prompt detection of such survival issues. Further research is required to unravel the burden and causative relationship of APT and primary tumors, as well as their socioeconomic impact on the survival population. 


\section{Ethics statement}

Written informed consent for retrospective analysis of melanoma patients in our registry was previously approved by local ethics committee (KEK-ZH 2014-0193).

\section{Author contributions}

Study concepts: Florentia Dimitriou, Phil Cheng, Reinhard Drummer; Study design: Florentia Dimitriou, Phil Cheng, Reinhard Dummer; Data acquisition: Florentia Dimitriou, Phil Cheng; Quality control of data and algorithms: Florentia Dimitriou, Phil Cheng; Data analysis and interpretation: Florentia Dimitriou, Phil Cheng; Statistical analysis: Phil Cheng, Patrick Turko; Manuscript preparation: Florentia Dimitriou; Manuscript editing: Florentia Dimitriou; Manuscript review: Phil Cheng, Reinhard Dummer, Joanna Mangana, Ralph Braun, Alessandra Curioni-Fontecedro, Markus Rechsteiner.

\section{ACKNOWLEDGMENTS}

Jan H. Rüschoff and K. Ikenberg from the Pathology and Molecular Pathology Department of the University Hospital of Zurich, for the Pathology analysis. Mrs. Isabell Pieper-Scholz for her contribution to the melanoma registry database.

\section{CONFLICTS OF INTEREST}

FD receives intermittent travel support from Amgen and Pierre Fabre outside of the submitted work; JM has intermittent project focused consultant or advisory relationships with Merck/Pfizer and Pierre Fabre and receives travel support from Merck Sharp \& Dohme und Pierre Fabre outside of the submitted work; ACF declares receipt of honoraria or consultation fees from AstraZeneca, Boehringer-Ingelheim, Bristol-Myers Squibb, F. Hoffmann-La Roche, Merck Sharp and Dohme, Novartis, Pfizer and Takeda as well as honorarium for talks in a company's organized public event from F. Hoffmann-La Roche and Merck Sharp and Dohme outside of the submitted work; RD has intermittent, project focused consulting and/or advisory relationships with Novartis, Merck Sharp \& Dhome (MSD), Bristol-Myers Squibb (BMS), Roche, Amgen, Takeda, Pierre Fabre, Sun Pharma, Sanofi outside the submitted work; MR, PT, RPB and PFC have declared no conflicts of interest.

\section{FUNDING}

This research did not receive any specific grant from funding agencies in the public, commercial, or notfor-profit sectors. The melanoma registry database of the Department of Dermatology has been partially supported by an unrestricted grant to the University of Zurich from Amgen, Novartis, BMS, MSD and Pierre Fabre.

\section{REFERENCES}

1. Balmain A. Cancer genetics: from Boveri and Mendel to microarrays. Nat Rev Cancer. 2001; 1:77-82. https://doi. org/10.1038/35094086. [PubMed]

2. Siegel RL, Miller KD, Jemal A. Cancer statistics, 2018. CA Cancer J Clin. 2018; 68:7-30. https://doi.org/10.3322/ caac. 21442. [PubMed]

3. Whiteman DC, Green AC, Olsen CM. The Growing Burden of Invasive Melanoma: Projections of Incidence Rates and Numbers of New Cases in Six Susceptible Populations through 2031. J Invest Dermatol. 2016; 136:1161-71. https://doi.org/10.1016/j.jid.2016.01.035. [PubMed]

4. Mort RL, Jackson IJ, Patton EE. The melanocyte lineage in development and disease. Development. 2015; 142:620-32. https://doi.org/10.1242/dev.106567. [PubMed]

5. Luke JJ, Flaherty KT, Ribas A, Long GV. Targeted agents and immunotherapies: optimizing outcomes in melanoma. Nat Rev Clin Oncol. 2017; 14:463-82. https://doi. org/10.1038/nrclinonc.2017.43. [PubMed]

6. Vogelstein B, Papadopoulos N, Velculescu VE, Zhou S, Diaz LA Jr, Kinzler KW. Cancer genome landscapes. Science. 2013; 339:1546-58. https://doi.org/10.1126/ science.1235122. [PubMed]

7. Cancer Genome Atlas N, and Cancer Genome Atlas Network. Genomic Classification of Cutaneous Melanoma. Cell. 2015; 161:1681-96. https://doi.org/10.1016/j. cell.2015.05.044. [PubMed]

8. Eroglu Z, Ribas A. Combination therapy with BRAF and MEK inhibitors for melanoma: latest evidence and place in therapy. Ther Adv Med Oncol. 2016; 8:48-56. https://doi. org/10.1177/1758834015616934. [PubMed]

9. Postow MA, Callahan MK, Wolchok JD. Immune Checkpoint Blockade in Cancer Therapy. J Clin Oncol. 2015; 33:1974-82. https://doi.org/10.1200/ JCO.2014.59.4358. [PubMed]

10. Ugurel S, Röhmel J, Ascierto PA, Flaherty KT, Grob JJ, Hauschild A, Larkin J, Long GV, Lorigan P, McArthur GA, Ribas A, Robert C, Schadendorf D, Garbe C. Survival of patients with advanced metastatic melanoma: the impact of novel therapies-update 2017. Eur J Cancer. 2017; 83:24757. https://doi.org/10.1016/j.ejca.2017.06.028. [PubMed]

11. Bradford PT, Freedman DM, Goldstein AM, Tucker MA. Increased risk of second primary cancers after a diagnosis of melanoma. Arch Dermatol. 2010; 146:265-72. https:// doi.org/10.1001/archdermatol.2010.2. [PubMed]

12. Cole-Clark D, Nair-Shalliker V, Bang A, Rasiah K, Chalasani V, Smith DP. An initial melanoma diagnosis may increase the subsequent risk of prostate cancer: Results from the New South Wales Cancer Registry. Sci Rep. 2018; 
8:7167. $\quad$ https://doi.org/10.1038/s41598-018-25408-6. [PubMed]

13. Giri S, Bhatt VR, Verma V, Pathak R, Bociek RG, Vose JM, Armitage JO. Risk of Second Primary Malignancies in Patients With Follicular Lymphoma: A United States Population-based Study. Clin Lymphoma Myeloma Leuk. 2017; 17:569-74. https://doi.org/10.1016/j. clml.2017.06.028. [PubMed]

14. Castillo JJ, Gertz MA. Secondary malignancies in patients with multiple myeloma, Waldenström macroglobulinemia and monoclonal gammopathy of undetermined significance. Leuk Lymphoma. 2017; 58:773-80. https://doi.org/10.1080 110428194.2016.1217527. [PubMed]

15. Corso G, Veronesi P, Santomauro GI, Maisonneuve P, Morigi C, Peruzzotti G, Intra M, Sacchini V, Galimberti V. Multiple primary non-breast tumors in breast cancer survivors. J Cancer Res Clin Oncol. 2018; 144:979-86. https://doi.org/10.1007/s00432-018-2621-9. [PubMed]

16. Li WQ, Qureshi AA, Ma J, Goldstein AM, Giovannucci EL, Stampfer MJ, Han J. Personal history of prostate cancer and increased risk of incident melanoma in the United States. J Clin Oncol. 2013; 31:4394-99. https://doi.org/10.1200/

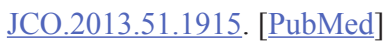

17. Hirvonen K, Rantanen M, Haapaniemi A, Pitkäniemi J, Malila N, Mäkitie AA. Second primary cancer after major salivary gland carcinoma. Head Neck. 2018; 40:251-58. https://doi.org/10.1002/hed.24937. [PubMed]

18. van der Leest RJ, Liu L, Coebergh JW, Neumann HA, Mooi WJ, Nijsten T, de Vries E. Risk of second primary in situ and invasive melanoma in a Dutch population-based cohort: 1989-2008. Br J Dermatol. 2012; 167:1321-30. https://doi. org/10.1111/j.1365-2133.2012.11123.x. [PubMed]

19. Leiter U, Buettner PG, Eigentler TK, Bröcker EB, Voit C, Gollnick H, Marsch W, Wollina U, Meier F, Garbe C. Hazard rates for recurrent and secondary cutaneous melanoma: an analysis of 33,384 patients in the German Central Malignant Melanoma Registry. J Am Acad Dermatol. 2012; 66:37-45. https://doi.org/10.1016/j. jaad.2010.09.772. [PubMed]

20. Pomerantz H, Huang D, Weinstock MA. Risk of subsequent melanoma after melanoma in situ and invasive melanoma: a population-based study from 1973 to 2011. J Am Acad Dermatol. 2015; 72:794-800. https://doi.org/10.1016/j. jaad.2015.02.006. [PubMed]

21. Lichtenstein P, Holm NV, Verkasalo PK, Iliadou A, Kaprio J, Koskenvuo M, Pukkala E, Skytthe A, Hemminki K. Environmental and heritable factors in the causation of cancer-analyses of cohorts of twins from Sweden, Denmark, and Finland. N Engl J Med. 2000; 343:78-85. https://doi.org/10.1056/NEJM200007133430201. [PubMed]

22. Tomasetti C, Vogelstein B, Parmigiani G. Half or more of the somatic mutations in cancers of self-renewing tissues originate prior to tumor initiation. Proc Natl Acad Sci USA. 2013; 110:1999-2004. https://doi.org/10.1073/ pnas.1221068110. [PubMed]
23. Mullenders LH. Solar UV damage to cellular DNA: from mechanisms to biological effects. Photochem Photobiol Sci. 2018; 17:1842-52. https://doi.org/10.1039/C8PP00182K. [PubMed]

24. Umansky V, Sevko A. Melanoma-induced immunosuppression and its neutralization. Semin Cancer Biol. 2012; 22:319-26. https://doi.org/10.1016/j. semcancer.2012.02.003. [PubMed]

25. Kamran N, Li Y, Sierra M, Alghamri MS, Kadiyala P, Appelman HD, Edwards M, Lowenstein PR, Castro MG. Melanoma induced immunosuppression is mediated by hematopoietic dysregulation. OncoImmunology. 2017; 7:e1408750. https://doi.org/10.1080/21624 02X.2017.1408750. [PubMed]

26. Polak ME, Borthwick NJ, Gabriel FG, Johnson P, Higgins B, Hurren J, McCormick D, Jager MJ, Cree IA. Mechanisms of local immunosuppression in cutaneous melanoma. Br J Cancer. 2007; 96:1879-87. https://doi. org/10.1038/sj.bjc.6603763. [PubMed]

27. Goggins W, Gao W, Tsao H. Association between female breast cancer and cutaneous melanoma. Int J Cancer. 2004; 111:792-94. https://doi.org/10.1002/ijc.20322. [PubMed]

28. Breast Cancer Linkage Consortium. Cancer risks in BRCA2 mutation carriers. J Natl Cancer Inst. 1999; 91:1310-16. https://doi.org/10.1093/jnci/91.15.1310. [PubMed]

29. Borg A, Sandberg T, Nilsson K, Johannsson O, Klinker M, Måsbäck A, Westerdahl J, Olsson H, Ingvar C. High frequency of multiple melanomas and breast and pancreas carcinomas in CDKN2A mutation-positive melanoma families. J Natl Cancer Inst. 2000; 92:1260-66. https://doi. org/10.1093/jnci/92.15.1260. [PubMed]

30. Tucker MA, Elder DE, Curry M, Fraser MC, Pichler V, Zametkin D, Yang XR, Goldstein AM. Risks of Melanoma and Other Cancers in Melanoma-Prone Families over 4 Decades. J Invest Dermatol. 2018; 138:1620-26. https:// doi.org/10.1016/j.jid.2018.01.021. [PubMed]

31. Loke TW, Seyfi D, Khadra M. Prostate cancer incidence in Australia correlates inversely with solar radiation. BJU Int. 2011; 108:66-70. https://doi.org/10.1111/j.1464410X.2011.10736.x. [PubMed]

32. Schwartz GG, Hanchette CL. UV, latitude, and spatial trends in prostate cancer mortality: all sunlight is not the same (United States). Cancer Causes Control. 2006; 17:1091-101. https://doi.org/10.1007/s10552-006-0050-6. [PubMed]

33. Luscombe CJ, Fryer AA, French ME, Liu S, Saxby MF, Jones PW, Strange RC. Exposure to ultraviolet radiation: association with susceptibility and age at presentation with prostate cancer. Lancet. 2001; 358:641-42. https://doi. org/10.1016/S0140-6736(01)05788-9. [PubMed]

34. Nair-Shalliker V, Smith DP, Egger S, Hughes AM, Kaldor JM, Clements M, Kricker A, Armstrong BK. Sun exposure may increase risk of prostate cancer in the high UV environment of New South Wales, Australia: a case-control 
study. Int J Cancer. 2012; 131:E726-32. https://doi. org/10.1002/ijc.27400. [PubMed]

35. Driscoll MS, Martires K, Bieber AK, Pomeranz MK, GrantKels JM, Stein JA. Pregnancy and melanoma. J Am Acad Dermatol. 2016; 75:669-78. https://doi.org/10.1016/j. jaad.2016.01.061. [PubMed]

36. Ramelyte E, Koelblinger P, Dummer R. Oestrogen receptor expression in melanoma. J Eur Acad Dermatol Venereol. 2017; 31:1399-400. https://doi.org/10.1111/jdv.14520. [PubMed]

37. Rampen FH, Mulder JH. Malignant melanoma: an androgen-dependent tumour? Lancet. 1980; 1:562-64. https://doi.org/10.1016/S0140-6736(80)91055-7. [PubMed]

38. Lu Y, Narayanan R, Wang J, Li W, Yepuru M, Liu L, Loveless VS, Miller DD. Abstract 1320: effects of selective androgen-receptor and estrogen-receptor modulators on telomerase activity in melanoma and prostate cancer cells. Cancer Res. 2013; 73:1320. https://doi.org/10.1158/15387445.AM2013-1320.

39. Oakley GM, Curtin K, Layfield L, Jarboe E, Buchmann LO, Hunt JP. Increased melanoma risk in individuals with papillary thyroid carcinoma. JAMA Otolaryngol Head
Neck Surg. 2014; 140:423-27. https://doi.org/10.1001/ jamaoto.2014.78. [PubMed]

40. Greenman C, Stephens P, Smith R, Dalgliesh GL, Hunter C, Bignell G, Davies H, Teague J, Butler A, Stevens C, Edkins S, O'Meara S, Vastrik I, et al. Patterns of somatic mutation in human cancer genomes. Nature. 2007; 446:153-58. https://doi.org/10.1038/nature05610. [PubMed]

41. Davies H, Bignell GR, Cox C, Stephens P, Edkins S, Clegg $\mathrm{S}$, Teague J, Woffendin H, Garnett MJ, Bottomley W, Davis N, Dicks E, Ewing R, et al. Mutations of the BRAF gene in human cancer. Nature. 2002; 417:949-54. https://doi. org/10.1038/nature00766. [PubMed]

42. Xing M. BRAF mutation in thyroid cancer. Endocr Relat Cancer. 2005; 12:245-62. https://doi.org/10.1677/ erc.1.0978. [PubMed]

43. Dummer R, Siano M, Hunger RE, Lindenblatt N, Braun R, Michielin O, Mihic-Probst D, von Moos R, Najafi Y, Guckenberger M, Arnold A. The updated Swiss guidelines 2016 for the treatment and follow-up of cutaneous melanoma. Swiss Med Wkly. 2016; 146:w14279. https:// doi.org/10.4414/smw.2016.14279. [PubMed] 